\title{
Risk factors and clinical disorders of canine ehrlichiosis in the South of Bahia, Brazil
}

\author{
Fatores de risco e alterações clínicas da erhlichiose canina no Sul da Bahia, Brasil \\ Renata Santiago Alberto Carlos ${ }^{1}$; Fábio Santos Carvalho²; Amauri Arias Wenceslau; \\ Nadia Regina Pereira Almosny ${ }^{3}$; George Rêgo Albuquerque ${ }^{1 *}$ \\ ${ }^{1}$ Departamento de Ciências Agrárias e Ambientais, Universidade Estadual de Santa Cruz - UESC \\ ${ }^{2}$ Programa de Pós-Graduação em Ciência Animal, Universidade Estadual de Santa Cruz - UESC \\ ${ }^{3}$ Departamento de Patologia Clínica Veterinária, Universidade Federal Fluminense - UFF
}

Received December 13, 2010

Accepted August 17, 2011

\section{Resumo}

Objetivou-se com este trabalho estudar as alteraçôes clínicas, fatores de risco da ehrlichiose canina nos municípios de Ilhéus e Itabuna, Bahia, e comparar diferentes métodos de diagnóstico. Amostras de sangue foram coletadas de 200 cães e cada animal foi examinado clinicamente. Foi preenchido um questionário para avaliar os fatores de risco. As amostras de sangue foram analisadas pelo teste Dot-ELISA e foram realizadas hematimetria, contagem de plaquetas e procura de mórulas em esfregaço de sangue. Nested-PCR foi realizada em 50 amostras positivas e 50 negativas na sorologia. Três amostras PCRs positivas foram seqüenciadas. Foi encontrado $36,0 \%$ de positividade na sorologia e $5,5 \%$ nos esfregaços sanguíneos. Os animais apresentavam anemia e trombocitopenia. Ter carrapatos e residir em áreas suburbanas foram considerados fatores de risco $(\mathrm{p}<0,05)$. A Nested-PCR identificou 11 cáes positivos, sendo 9 com sorologia positiva e 2 negativos. O sequenciamento de DNA foi compatível com a presença de Ehrlichia canis.

Palavras-chave: Ehrlichia canis, epidemiologia, ELISA, Nested PCR.

\begin{abstract}
The aim of this work was to study the clinical disorders and risk factors of canine ehrlichiosis in Ilhéus and Itabuna, Bahia, and compare different diagnostic methods. Blood samples were collected from 200 dogs. Each dog was clinically examined. A questionnaire was used to evaluate the risk factors. The blood samples were analyzed using the Dot-ELISA test; hematometry, platelet counts and searches for morulae on blood smears were performed. Nested PCR was carried out on 50 serologically positive samples and 50 negative samples. Three positive PCRs were sequenced. Thirty-six percent were serologically positivity and $5.5 \%$ from blood smears. The animals were anemic and thrombocytopenic. Presence of ticks and living in areas on the urban periphery were considered to be risk factors $(\mathrm{p}<0.05)$. Nested PCR identified 11 positive dogs of which nine were serologically positive and two were negative. The DNA sequencing was consistent with the presence of Ehrlichia canis.
\end{abstract}

Keywords: Ehrlichia canis, epidemiology, ELISA, Nested PCR.

\section{Introduction}

Ehrlichia canis is the agent for canine monocytic ehrlichiosis (CME), which is transmitted by ticks, especially Rhipicephalus sanguineus. The first clinical manifestations occurred after an incubation period that varies from 8 to 20 days, with three distinct infection phases: acute, subclinical and chronic (HARRUS et al., 1997). Clinical signs such as fever, anorexia, vomiting, weight loss, hepatomegaly, splenomegaly, lymphadenopathy, epistaxis and hemorrhage are observed (HARRUS et al., 1997; MOREIRA et al.,

\footnotetext{
*Corresponding author: George Rêgo Albuquerque

Departamento de Ciências Agrárias e Ambientais, Universidade Estadual de

Santa Cruz - UESC, CEP 45662-900, Ilhéus - BA, Brazil;

e-mail: gralbu@uesc.br
}

2003). Thrombocytopenia and anemia are the most common blood abnormalities in dogs that have been naturally or experimentally infected (M'GHIRBI et al., 2009).

Epidemiological studies in Brazil have revealed that the seroprevalence of CME ranges from 1.7 to $65.6 \%$ among dogs in urban or rural environments (LABARTHE et al., 2003; COSTA JUNIOR et al., 2007). Early diagnosis of ehrlichiosis is important because this is an emerging zoonotic disease (PEREZ et al., 2006). The diagnostic techniques available include blood smears to view inclusions of corpuscles or morulae (BORIN et al., 2009), serum tests, especially Dot-ELISA and the indirect immunofluorescence assay (IFA) (TRAPP et al., 2006), and molecular techniques such as nested PCR (SOUZA et al., 2010). 
The aim of the present study was to describe the clinical disorders and risk factors of canine ehrlichiosis in Ilhéus and Itabuna, Bahia, and compare the different diagnostic methods.

\section{Materials and Methods}

\section{Location}

This study was conducted in Ilhéus (Latitude $14^{\circ} 47^{\prime} \mathrm{S}$ and Longitude $39^{\circ} 02^{\prime} \mathrm{W}$ ) and Itabuna (latitude $14^{\circ} 47^{\prime} \mathrm{S}$ and longitude $\left.39^{\circ} 16^{\prime} \mathrm{W}\right)$, in the Southern region of the State of Bahia, from August 2004 to April 2005. During the study period, the average temperature was $23.4{ }^{\circ} \mathrm{C}$, with relative humidity of $84.8 \%$ and total rainfall of $1,320 \mathrm{~mm}$.

\section{Population studied, samples and procedures}

Blood samples were collected from 200 dogs (100 dogs per city) at the Veterinary Teaching Hospital of the State University of Santa Cruz (UESC) (Ilhéus $\mathrm{n}=35$, Itabuna $\mathrm{n}=20$ ), at participating local veterinary clinics (Ilhéus $n=20$, Itabuna $n=45$ ), and selected households in both cities (Ilhéus $n=45$, Itabuna $n=35$ ). The animals were selected for the researchers' convenience, without specific inclusion criteria, exclusion criteria or randomization. At the local veterinary clinics, dogs were enrolled in this study when they were presented due to illness or the need for a surgical procedure or annual checkup. The participating households were invited to join in by staff at the clinics and were selected based on the owners' willingness to participate in this study. Only one dog per household was enrolled.

Any clinical abnormalities identified from each dog's history or during the physical examination were recorded. The epidemiological questionnaire was filled out by the owner, and the variables studied were gender (male, female), age (1-4 years, $>4$ years), contact with other dogs (yes, no), presence of ticks (yes, no), breed (purebred, mixed-breed), wellness care (yes, no), petechiae (presence, absence), apathy (presence, absence), fever (presence, absence), dehydration (presence, absence), lymphadenopathy (presence, absence), weight loss (presence, absence) and household location (urban, urban periphery). The dogs living on the urban periphery were in households in peripheral neighborhoods, i.e. outside the urban centers of the cities. Thrombocytopenia (presence, absence) and anemia (presence, absence) were included in the analysis based on the hematological tests.

Blood samples were collected into tubes with and without EDTA. Blood samples were examined for E. canis antibodies using a commercial kit for dot-ELISA (Snap 3DX ${ }^{\oplus}$, IDEXX Laboratories), in accordance with the manufacturer's instructions. Blood smears were prepared, fixed in methanol for 5 minutes and stained with $10 \%$ Giemsa. Complete blood counts were performed. Dogs with counts of less than 200,000 platelets. $\mathrm{mL}^{-1}$ were considered to be thrombocytopenic (HARRUS et al., 1997). Animals with packed cell volume (PCV) below 37\% were considered anemic.

Fifty seropositive and 50 seronegative dogs were tested by means of nested PCR for molecular detection of E. canis. Only 100 PCRs were possible because of losses of several samples at the beginning of the study. DNA was extracted from $100 \mathrm{~mL}$ of EDTA blood using a commercial kit (ChargeSwitch ${ }^{\mathrm{TM}}$ gDNA 50-100 mL Blood Kit, Invitrogen ${ }^{\mathrm{TM}}$, USA), in accordance with the manufacturer's instructions, thus resulting in a final DNA concentration of at least $3 \mathrm{mg}$ of total extracted volume. Molecular-grade water was extracted to confirm that there was no cross-contamination between samples during DNA extraction. The genetic presence of any species of the Ehrlichia genus was investigated using the ECC forward primer (5'AGAACGAACGCTGGCGGCAAGC-3') and ECB reverse primer (5'-CGTATTACCGCGGCTGCTGGCA-3'). Samples that were positive for Ehrlichia sp. were then tested with the ECAN5 forward primer (5'-CAATTATTTATAGCCTCTGGCTATAGGA-3') and $\mathrm{HE} 3$ reverse primer (5' - TATAGGTACCGTCA TTATCTTCCCTAT-3') to obtain a specific amplification of E. canis. The PCR mixture consisted of $5 \mathrm{~mL}$ of purified DNA, $0.4 \mathrm{mM}$ of ECB/ECC, $200 \mathrm{mM}$ of each dNTP, $5.0 \mathrm{mM}$ of $\mathrm{MgCl}_{2}, 2.5 \mathrm{U}$ of Taq DNA polymerase (Invitrogen ${ }^{\mathrm{TM}}$ ) and 1.6x PCR buffer (Invitrogen ${ }^{\mathrm{TM}}$ ), to make up a total volume of $25 \mathrm{~mL}$ of reaction mixture. The amplification program used to identify the genetic sequence of the genus Ehrlichia spp. consisted of a first step of denaturation for 3 minutes at $94^{\circ} \mathrm{C}$, followed by 35 cycles of denaturation at $94^{\circ} \mathrm{C}$ for 1 minute, annealing at $68{ }^{\circ} \mathrm{C}$ for 2 minutes and extension at $72{ }^{\circ} \mathrm{C}$ for 2 minutes. For the nested PCR, $3 \mathrm{~mL}$ of amplicons from the first PCR and $0.2 \mathrm{mM}$ of ECAN5/HE3 were used to identify the specific genetic sequence for $E$. canis, in an amplification program consisting of denaturation for 3 minutes at $94^{\circ} \mathrm{C}$, followed by 35 denaturation cycles at $94^{\circ} \mathrm{C}$ for 1 minute, annealing at $58{ }^{\circ} \mathrm{C}$ for 2 minutes and extension at $72{ }^{\circ} \mathrm{C}$ for 1.5 minute. The PCR products were analyzed using $1.5 \%$ agarose gel electrophoresis, stained with ethidium bromide and photographed. The positive control used was a blood sample from a dog that was positive for E. canis, and which had previously been confirmed by sequencing. For the negative control, ultra-pure water was used in both PCRs.

The sequencing of the samples was carried out using the automatic sequencer ABI-PRISM 3100 Genetic Analyzer (Applied Biosystems). The DNA template (45 ng) was marked with 3.2 pmol of the primer ECAN 5 and $2 \mathrm{~mL}$ of the reagent BigDye Terminator v3.1 Cycle Sequencing RR-100 (Applied Biosystems), in a final volume of $10 \mathrm{~mL}$. The BLAST software (http://www. ncbi.nlm.nih.gov/blast) was used for comparison and analysis of the sequences obtained.

\section{Statistical analysis}

Normal data distribution was confirmed by means of the Kolmogorov-Smirnov test in the SPSS software, and statistical differences in platelet counts and PCV between $E$. canis seropositive and seronegative dogs were analyzed by means of the $t$-test, to 5\% (RODRIGUEZ-VIVAS et al., 2005).

The association between presence of antibodies against $E$. canis and the study variables was evaluated by means of the chi-square $\left(\chi^{2}\right)$ test and Fisher's exact test. The Epi-Info software, version 3.5.1, was used to evaluate the dispersion frequency. The variables that presented $\mathrm{P}<0.2$ in the univariate analysis were selected for multivariate analysis by means of logistic regression, also using the Epi-Info software, version 3.5.1. 


\section{Results}

Out of all the samples tested, $72(36 \%)$ were positive for E. canis according to ELISA Snap 3DX: 43 in Ilhéus and 29 in Itabuna (CARLOS et al., 2007). In relation to the place where the samples were collected, the rates of positive findings were $52.7 \%$ (29) at the Veterinary Hospital, 26.15\% (17) for the dogs at private veterinary clinics and 32.5\% (26) among samples collected from households. Evaluating according to municipality, the rates of positive findings in Ilhéus were 65.7\% (23) for the samples collected at UESC, 35\% (7) in private veterinary clinics and $28.9 \%$ (13) from households. In Itabuna, the rates of positive findings were $30 \%$ (6) at UESC, $22.2 \%$ (10) in veterinary clinics and $37.1 \%$ (13) from households. A statistical difference was observed in relation to the samples collected in Ilhéus, at UESC $(\mathrm{p}=0.02)$. Only $11 \mathrm{dogs}(5.5 \%)$ presented typical morulae in monocytes (Table 1).

The clinical examination detected fever $(\mathrm{n}=24,12.0 \%)$, apathy $(\mathrm{n}=13,6.5 \%)$, petechiae $(\mathrm{n}=3,1.5 \%)$, dehydration $(\mathrm{n}=13$, $6.5 \%)$, lymphadenopathy $(\mathrm{n}=49,24.5 \%)$, and weight loss $(\mathrm{n}=10$, $5.0 \%$ ). Among the 72 seropositive animals, 10 presented fever

Table 1. Presence of ectoparasites, morulae and antibodies against Ehrlichia canis in dogs in the Southern region of Bahia.

\begin{tabular}{lcccc}
\hline Location & Dogs & $\begin{array}{c}\text { Dogs with } \\
\text { ticks }\end{array}$ & $\begin{array}{c}\text { Presence of } \\
\text { morulae }\end{array}$ & $\begin{array}{c}\text { Presence of } \\
\text { antibodies }\end{array}$ \\
\hline Ilhéus & 100 & 54 & 6 & 43 \\
Itabuna & 100 & 40 & 5 & 29 \\
Total & 200 & 94 & 11 & 72 \\
\hline
\end{tabular}

(13.8\%), 9 apathy (12.5\%), 3 petechiae (4.2\%), 7 dehydration (9.7\%) and 28 lymphadenopathy (38.9\%). All the animals with petechiae were seropositive.

The average number of platelets was 249,000 (range: $23,000-628,000)$ platelets. $\mathrm{mL}^{-1}$ of blood. The seropositive dogs presented an average count of 180,000 platelets. $\mathrm{mL}^{-1}$ of blood (range: 23,000 - 590,000). The seronegative dogs presented an average of 288,000 platelets. $\mathrm{mL}^{-1}$ of blood (range: $76,000-628,000)(\mathrm{p}<0.0001)$. Regarding hematocrit values, the total average was $40.5 \%$ (range: $8.0-60.0$ ). The seropositive animals presented an average of $35.2 \%$ (range: $8.0-56.0$ ) whereas the seronegative animals presented an average of $43.5 \%$ (range: $22.0-60.0)(\mathrm{p}<0.0001)$.

The univariate analysis used to identify risk factors for $E$. canis seropositivity are presented in Table 2 . Logistic regression revealed a positive relationship between the presence of ticks and dogs living on the urban periphery (Table 3). Regarding clinical abnormalities, based on univariate analysis, seropositive animals more frequently were anemic $(\mathrm{p} \leq 0.01)$ and thrombocytopenic $(\mathrm{p} \leq 0.01)$ and presented lymphadenopathy $(\mathrm{p} \leq 0.01)$, in comparison with seronegative dogs. There were no differences in temperature between the groups (Table 4). Logistic regression revealed positive relationships with anemia, thrombocytopenia and lymphadenopathy (Table 5).

Among the 100 blood samples tested for E. canis DNA by means of nested PCR, 11 were considered positive. Out of these, nine were from seropositive dogs and two from seronegative dogs. All the sequenced fragments had approximately 364 base pairs (bp). These sequences had $97-99 \%$ identicality with the corresponding sequences of $E$. canis strains that have been deposited at GenBank (access codes: GU386289.1; GU386285.1).

Table 2. Univariate analysis on risk factors associated with seroprevalence of Ehrlichia canis in dogs in Ilhéus and Itabuna, Bahia.

\begin{tabular}{|c|c|c|c|c|c|c|}
\hline Variable & $\mathbf{N}$ & Positive dogs & Prevalence (\%) & OR & $95 \% \mathrm{CI}$ & P-value \\
\hline \multicolumn{7}{|l|}{ Gender } \\
\hline Female & 93 & 33 & 35.48 & - & - & - \\
\hline Male & 107 & 39 & 36.45 & 1 & $0.5-1.9$ & 0.99 \\
\hline \multicolumn{7}{|l|}{ Age (years) } \\
\hline $1-4$ & 109 & 36 & 33.03 & - & - & - \\
\hline$>4$ & 91 & 36 & 39.56 & 0.75 & $0.4-1.4$ & 0.41 \\
\hline \multicolumn{7}{|l|}{ Breed } \\
\hline Mixed breed & 139 & 44 & 31.65 & - & - & - \\
\hline Pure breed & 61 & 28 & 45.90 & 1.83 & $0.9-3.6$ & 0.07 \\
\hline \multicolumn{7}{|l|}{ Ticks } \\
\hline Presence & 95 & 43 & 45.26 & 2.17 & $1.1-4.1$ & 0.01 \\
\hline Absence & 105 & 29 & 27.62 & - & - & - \\
\hline \multicolumn{7}{|l|}{ Household } \\
\hline Urban periphery & 45 & 27 & 62.5 & 3.67 & $1.7-7.7$ & 0.0002 \\
\hline Urban & 155 & 45 & 27.5 & - & - & - \\
\hline \multicolumn{7}{|l|}{ Wellness care } \\
\hline Yes & 138 & 43 & 31.2 & 0.52 & $0.27-1.0$ & 0.049 \\
\hline No & 62 & 29 & 46.8 & - & - & - \\
\hline \multicolumn{7}{|c|}{ Contact with other dogs } \\
\hline Yes & 148 & 54 & 36.5 & 0.92 & $0.4-1.7$ & 0.94 \\
\hline No & 52 & 18 & 34.5 & - & - & - \\
\hline
\end{tabular}

95\% CI: 95\% confidence interval; OR: odds ratio (relative risk); P-value: probability. 


\section{Discussion}

The results obtained from this study showed that dogs from the cities of Ilhéus and Itabuna, in the State of Bahia, Brazil, are exposed to E. canis. The serum prevalence in this study was similar to that found by Souza et al. (2010) using IFA, which found a prevalence of $35.6 \%$ in Salvador, Bahia. Using the Dot-ELISA test on 2,553 dogs from several Brazilian States, Labarthe et al. (2003) found that $505(19.8 \%)$ were positive, with highest prevalence in the States of the Northeast (43\%) and lowest in the Southern region $(1.7 \%)$. Among the 2,553 dogs, 117 of the samples were collected in Salvador, and 42 (35.9\%) were positive, which was also similar to the present study. In the same region of Bahia, with 153 different dogs, Carvalho et al. (2008) found using PCR that $12(7.8 \%)$ were positive. In the present study, there was a statistical difference in relation to the dog samples from UESC in Ilhéus, because the majority of these animals came from the urban periphery, which was considered to be a risk factor for infection.

The serum prevalence of $E$. canis varies according to climatic conditions and certain epidemiological factors, such as the

Table 3. Final result from logistic regression on risk factors associated with Ehrlichia canis exposure in dogs in Ilhéus and Itabuna, Bahia.

\begin{tabular}{lccc}
\hline \multicolumn{1}{c}{ Variable } & OR & $\mathbf{9 5 \%}$ CI & P-value \\
\hline Household & & & \\
\hline Urban periphery & 1.00 & - & - \\
Urban & 0.30 & $0.15-0.62$ & 0.001 \\
\hline Ticks & & & \\
\hline No & 1.00 & - & - \\
Yes & 1.81 & $0.98-3.35$ & 0.05 \\
\hline
\end{tabular}

95\% CI: 95\% confidence interval; OR: odds ratio (relative risk); P-value: probability. presence and distribution of the vector, the animal's behavior, the age and type of the population under study, and the habitat (RODRIGUEZ-VIVAS et al., 2005). The dogs that lived on the urban periphery presented a higher seropositivity rate for $E$. canis $(\mathrm{ORS}=3.7)$ than shown by those in the urban area. The same association was observed by Trapp et al. (2006). These results suggest that dogs that live on the urban periphery are more exposed to vector ticks, which may be related to the fact that urban dogs are more frequently sprayed with acaricides than are dogs on the urban periphery or rural dogs.

The weather is an important factor that influences the population dynamics of ticks. The average temperature in the region of Ilhéus and Itabuna provides excellent conditions for $R$. sanguineus ticks, the natural vector for $E$. canis, to develop. Ticks were found on $59.7 \%$ of the positive animals, whereas on $59.4 \%$ of the negative animals, this vector was not found. Presence of the tick as a risk factor for ehrlichiosis was also detected by Trapp et al. (2006) and Costa Junior et al. (2007).

A higher rate of seronegative animals ( $p=0.049)$ was also observed among the dogs that were not provided with wellness care, thereby showing that visits to veterinary clinics were a protection factor. This is explained by the care that owners provide for their animals and the consequent lower infestation rate by the vector.

The main clinical signs observed during clinical examinations were similar to those described by Moreira et al. (2003) and Borin et al. (2009). Ehrlichia canis may cause variable signs, which make the diagnosis more challenging. The hematological abnormalities identified in the present study (thrombocytopenia and anemia) were similar to those previously described by Rodriguez-Vivas et al. (2005), Borin et al. (2009) and M'Ghirbi et al. (2009). The effects of the mononuclear phagocytic system, cell lysis mediated by the complement system and suppression of erythropoiesis at the bone marrow may be the mechanisms responsible for the anemia

Table 4. Univariate analysis on clinical and hematological abnormalities in dogs exposed to Ehrlichia canis in Ilhéus and Itabuna, Bahia.

\begin{tabular}{|c|c|c|c|c|c|c|}
\hline Variable & $\mathbf{N}$ & + & Prevalence (\%) & OR & 95\% CI & P-value \\
\hline \multicolumn{7}{|l|}{ Fever } \\
\hline Yes & 24 & 10 & 41.7 & - & - & - \\
\hline No & 176 & 62 & 35.2 & 0.76 & $0.30-1.98$ & 0.69 \\
\hline \multicolumn{7}{|l|}{ Petechiae } \\
\hline Yes & 3 & 3 & 100.0 & - & - & - \\
\hline No & 197 & 69 & 35.0 & - & - & $0.045^{*}$ \\
\hline \multicolumn{7}{|l|}{ Apathy } \\
\hline Yes & 13 & 9 & 69.2 & 4.43 & $1.18-17.87$ & 0.022 \\
\hline No & 187 & 63 & 33.7 & - & - & - \\
\hline \multicolumn{7}{|l|}{ Lymph nodes } \\
\hline Normal & 151 & 44 & 29.1 & - & - & - \\
\hline Increased & 49 & 28 & 57.1 & 3.24 & $1.58-6.67$ & 0.0007 \\
\hline \multicolumn{7}{|l|}{ Thrombocytopenia } \\
\hline Yes & 76 & 48 & 63.2 & 7.14 & $3.58-14.38$ & $<0.0001$ \\
\hline No & 124 & 24 & 19.4 & - & - & - \\
\hline \multicolumn{7}{|l|}{ Anemia } \\
\hline Yes & 78 & 42 & 53.8 & 3.58 & $1.87-6.88$ & $<0.0001$ \\
\hline No & 122 & 30 & 24.6 & - & - & - \\
\hline \multicolumn{7}{|l|}{ Dehydration } \\
\hline Yes & 13 & 7 & 53.8 & - & - & - \\
\hline No & 187 & 65 & 34.8 & 0.45 & $0.14-1.41$ & 0.27 \\
\hline
\end{tabular}

95\% CI: 95\% confidence interval; OR: odds ratio (relative risk); P-value: probability. ${ }^{*}$ Fisher's exact test. 
Table 5. Final result from logistic regression on clinical and hematological abnormalities in dogs exposed to Ehrlichia canis in Ilhéus and Itabuna, Bahia.

\begin{tabular}{lccc}
\hline Variable & OR & $\mathbf{9 5 \%}$ CI & P-value \\
\hline Anemia & & & \\
\hline Yes & 2.25 & $1.13-4.51$ & 0.02 \\
No & 1.00 & - & - \\
\hline Thrombocytopenia & & & \\
\hline Yes & 6.60 & $3.32-13.12$ & $<0.0001$ \\
No & 1.00 & - & - \\
\hline Lymph nodes & & & \\
\hline Normal & 0.34 & $0.15-0.75$ & 0.007 \\
$\quad$ Increased & 1.00 & & \\
\hline
\end{tabular}

95\% CI: 95\% confidence interval; OR: odds ratio (relative risk); P-value: probability.

relating to the disease (MOREIRA et al., 2003). Ehrlichia canis induces thrombocytopenia through destruction and consumption of platelets, increased hepatic or splenic platelets sequestration, decreased platelet production due to bone marrow hypoplasia (WOODY; HOSKINS, 1991) and production of antiplatelet antibodies (GAUNT et al., 2010).

Diagnosing of ehrlichiosis through blood smear analysis is difficult because intracytoplasmic morulae are only occasionally seen during the acute phase of the disease (RODRIGUEZ-VIVAS et al., 2005). In the present study, we observed that 5.5\% of the blood smears presented the typical morulae of E. canis, and this was similar to the observations of Rodriguez-Vivas et al. (2005), who found that $44.1 \%$ of the dogs were seropositive but that only six dogs $(5 \%)$ presented morulae detected in blood smears.

Serological tests (dot-ELISA and IFA) are the method most commonly used for veterinary diagnosis. However, the fact that an animal is seropositive does not mean that it is sick. Since the presence of antibodies reveals exposure to the agent, PCR may help in reaching a diagnostic conclusion. Souza et al. (2010) found that $35.6 \%(168 / 472)$ of the dogs examined were seropositive, but that only $58(34.5 \%)$ of these animals were PCR-positive.

In the present $s$ udy, nested PCR was used on 100 samples (50 seropositive and 50 seronegative for E. canis), and nine dogs were found to be PCR-positive among the seropositive dogs. It was found that two dogs were seronegative for $E$. canis, but PCR-positive. Similar results were obtained by Diniz et al. (2007). Hyperacute cases may be PCR-positive with no antibody response, in which the molecular test detects the presence of the agent before the dog's immunological response occurs. Nested PCR is the technique most used for diagnosing E. canis, but false-positive results may occur if primers that generate unspecific fragments are used. In the present study, such results did not occur because the primers used were ECAN5 and HE-3. In sequencing the E. canis DNA fragments using the ECAN5 primer, the homology ranged from 97 to $99 \%$. This low homology may have occurred because of the few samples sequenced (three), as well as incomplete DNA purification prior to sequencing.

In the present study, subject enrollment done according to convenience, because of certain constraints, such as structural and financial limitations. Despite the lack of random sampling in this study, the results provide important information about disease prevalence and the risk factors and clinical abnormalities associated with E. canis infection in the Southern region of Bahia.

\section{References}

BORIN, S.; CRIVELENTI, L. Z.; FERREIRA, F. A. Aspectos epidemiológicos, clínicos e hematológicos de 251 cáes portadores de mórula de Ehrlichia spp. naturalmente infectados. Arquivo Brasileiro de Medicina Veterinária e Zootecnia, v. 61, n. 3, p. 566-571, 2009.

CARLOS, R. S. A. et al. Frequência de anticorpos anti-Erhlichia canis, Borrelia burgdorferi e antígenos de Dirofilaria immitis em cães na microrregiấo Ilhéus-Itabuna, Bahia, Brasil. Revista Brasileira de Parasitologia Veterinária,v. 16, n. 3, p. 117-120, 2007.

CARVALHO, F. S. et al. Epidemiological and molecular study of Ehrlichia canis in dogs in Bahia, Brazil. Genetics and Molecular Research, v. 7, n. 3, p. 657-662, 2008. PMid:18752193. http://dx.doi. org/10.4238/vol7-3gmr468

COSTA JUNIOR, L. M. et al. Sero-prevalence and risk indicators for canine ehrlichiosis in three rural areas of Brazil. Veterinary Journal, v. 174, n. 3, p. 673-676, 2007. PMid:17204439. http://dx.doi. org/10.1016/j.tvjl.2006.11.002

DINIZ, P. P. V. P et al. Surveillance for zoonotic vector-borne infections using sick dogs from southeastern Brazil. Vector-Borne and Zoonotic Diseases,v. 7, n. 4, p. 689-697, 2007.

GAUNT, S. D. et al. Experimental infection and co-infection of dogs with Anaplasma platys and Ehrlichia canis: hematologic, serologic and molecular findings. Parasites and Vectors, v. 3, n. 1, p. 33, 2010. http://dx.doi.org/10.1186/1756-3305-3-33

HARRUS, S. et al. Canine monocytic ehrlichiosis: an update. Parasitology, v. 19, p. 431-444, 1997.

LABARTHE, N. et al. Serologic prevalence of Dirofilaria immitis, Ehrlichia canis, and Borrelia burgdorferi infections in Brazil. Veterinary Therapeutics, v. 4, p. 67-75, 2003.

M'GHIRBI, Y. et al. Clinical, serological and molecular evidence of ehrlichiosis and anaplasmosis in dogs in Tunisia. Parasitology Research, v. 104, n. 4 , p. $767-774,2009$.

MOREIRA, S. M. et al. Retrospective study (1998-2001) on canine ehrlichiosis in Belo Horizonte, MG, Brazil. Arquivo Brasileiro de Medicina Veterinária e Zootecnia, v. 55, n. 2, p. 141-147, 2003.

PEREZ, M. et al. Human infection with Ehrlichia canis accompanied by clinical signs in Venezuela. Annals of New York Academic Science, v. 1078, p. 110-117, 2006. PMid:17114689. http://dx.doi.org/10.1196/ annals. 1374.016

RODRIGUEZ-VIVAS, R. I.; ALBORNOZ, R. E. F.; BOLIO, G. M. E. Ehrlichia canis in dogs in Yucatan, México: seroprevalence, prevalence of infection and associated factors. Veterinary Parasitology, v. 127, n. 1, p. 75-79, 2005. PMid:15619376. http://dx.doi.org/10.1016/j. vetpar.2004.08.022

SOUZA, B. M. P. S. et al. Prevalence of ehrlichial infection among dogs and ticks in Northeastern Brazil. Revista Brasileira de Parasitologia Veterinária, v. 19, n. 2, p. 89-93, 2010.

TRAPP, S. M. et al. Seroepidemiology of canine babesiosis and ehrlichiosis in a hospital population. Veterinary Parasitology, v. 140, n. 3-4, p. 223-230, 2006. PMid:16647817. http://dx.doi.org/10.1016/j. vetpar.2006.03.030

WOODY, B. J.; HOSKINS, J. D. Ehrlichial diseases of dogs. Veterinary Clinics of North America: Small Animal Practice, v. 21, n. 1, p. 75-98, 1991. PMid:2014630. 